\title{
CARMONA VISTA A TRAVÉS DE LOS JESUITAS (1619-1754)
}

\author{
Felipe Pizarro Alcalde \\ Universidad Complutense de Madrid
}

\section{RESUMEN}

Las Historias que escribieron los numerosos colegios de la Compañía de Jesús constituyen una fuente fundamental para acercarnos al estudio de la Orden fundada por San Ignacio de Loyola en 1540, además de poder analizar múltiples aspectos de la sociedad sobre la que se asientan. Desde el principio estos centros tuvieron un enorme éxito y llegaron a ser uno de los exponentes más influyentes en el espíritu de la reforma católica. Estos manuscritos siguen una misma estructura y la información que contienen es muy parecida. En este estudio analizaremos los datos que nos ofrece uno de ellos: la Historia del Colegio de Carmona (1619-1754).

PALABRAS CLAVE Carmona, Compañía de Jesús, jesuitas, Pedro de Hoyos y San Teodomiro.

\section{ABSTRACT}

The histories that wrote the numerous colleges of the Jesus' Company are a fundamental source to bring near us to the order's research that was founded by Saint Ignacio of Loyola in 1540, as well as to can analyze many aspects of the society where they were settled. From the beginning, these centres had an enormous exit and they were one of the exponents more influential in the spirit of the Catholic's reform. These manuscripts follow the same structure and the information than contained is very similar. In this research, we will analyze the dates that offer us one of them: the College Carmona's History (1619-1754).

KEY WORDS Carmona, jesuits, Jesus’ Company, Pedro de Hoyos and Saint Teodomiro. 


\section{Introducción}

Este estudio pretende mostrar la abundante y rica información recogida en las Historias de los colegios jesuitas, manuscritos ordenados escribir por los generales de la Compañía de Jesús, en especial la dedicada a la ciudad sevillana de Carmona ${ }^{1}$. Si en otra ocasión se utilizó para dibujar algunos rasgos propios de la Orden², ahora profundizaremos en el análisis local desde el punto de vista social, demográfico, económico, religioso o artístico, sin olvidar la mentalidad de la época. Dada la escasez de fuentes existentes para conocer la realidad carmonense de los siglos modernos, este documento resulta de gran importancia.

\section{La Compañía de Jesús y las historias de los colegios}

Ignacio de Loyola decidió fundar una orden religiosa, la Compañía de Jesús, cuyos miembros se llamarían jesuitas ${ }^{3}$. El 27 de septiembre de 1540 el papa Paulo III concedía la bula Regimini militantis Ecclesiae y aprobaba el Instituto ${ }^{4}$. Posteriormente se redactó una nueva fórmula, aprobada por Julio III, expuesta en la bula Exposicit debitum, de 21 de julio de 1550. Los jesuitas constituyeron uno de los movimientos más importantes y novedosos del siglo XVI. Dentro del contexto contrarreformista, participaron activamente en los debates del Concilio de Trento (1545-1563) ${ }^{5}$. Los regulares defendieron y propagaron las nuevas directrices establecidas a través de la predicación y creación de instituciones dedicadas a la enseñanza, colegios y universidades, con un afán renovador e

1 Este estudio está basado en el trabajo de investigación El Colegio de San Teodomiro de la Compañía de Jesús en Carmona (1620-1754), dirigido por el Dr. Fermín Marín Barriguete, que fue leído en el Departamento de Historia Moderna de la Universidad Complutense de Madrid el 30 de mayo de 2003. Quiero agradecer al director su apoyo y orientación, además de a todos los bibliotecarios y archiveros, especialmente al padre Torres, responsable del Archivo Provincial de Toledo durante los meses que transcurrió la investigación. Se consultaron los siguientes fondos documentales: A.P.T.S.I. (Archivo Provincial de Toledo Societatis Iesu), B.N. (Biblioteca Nacional de Madrid) e I.H. (CSIC) F.A. G-374 (Instituto de Historia del Consejo Superior de Investigaciones Científicas, Fondo Antiguo).

2 PIZARRO ALCALDE, Felipe: "Una fuente para profundizar en el estudio de la Compañía de Jesús: las Historias de los Colegios” en Tiempos Modernos (en prensa).

3 LOYOLA, Ignacio de: Obras completas, Madrid, 1963.

4 La bibliografía sobre la Compañía de Jesús es amplia, aunque con carácter general podemos destacar los siguientes estudios: ASTRAIN, Antonio: Historia de la Compañía de Jesús en la Asistencia de España, 7 tomos, Madrid, 1921-1925. En esta investigación se han utilizado, sobre todo, dos de ellos: Historia de la Compañía de Jesús en la Asistencia de España. Aquaviva 1585-1615 (Segunda Parte), tomo IV, Madrid, 1913, y la Historia de la Compañía de Jesús en la Asistencia de España. Vitelleschi, Carafa, Piccolomini 1615-1652, tomo V, Madrid, 1916; BANGERT, William V.: Historia de la Compañía de Jesús, Santander, Sal Terrae, 1981; BRODRICK, James: Origen y evolución de los jesuitas, 2 vols., Madrid, Pegaso, 1955; EGIDO, Teófanes (coord.), BURRIEZA SÁNCHEZ Javier y REVUELTA GONZÁLEZ, Manuel: Los jesuitas en España y en el mundo hispánico, Madrid, Marcial Pons, 2004; GARCÍA-VILLOSLADA, Ricardo: Manual de Historia de la Compañía de Jesús, Madrid, Compañía Bibliográfica Española, 1954; LACOUTURE, Jean: Jesuitas. I. Los conquistadores, Barcelona, Paidós Ibérica, 1994; MARTIN, Malachi: Los jesuitas. La Compañía de Jesús y la traición a la Iglesia católica, Barcelona, Plaza \& Janés, 1988; y O’NEILL, Charles E. y DOMíNGUEZ, José María (dirs.): Diccionario histórico de la Compañía de Jesús: biográfico-temático, 4 vols., Madrid, Universidad Pontificia de Comillas, 2001.

5 Sobre el Concilio de Trento y sus resoluciones, véase: CRISTIANI, León: Trento en A. FLICHÉ y V. MARTIN (dirs.), Historia de la Iglesia, vol. XIX, Valencia, EDICEP, 1976; ISERLOH, Erwin y GLAZIK, Josef: Reforma, reforma católica y contrarreforma en H. JEDIN (dir.), Manual de Historia de la Iglesia, tomo V, Barcelona, Herder, 1972 o VERDOY, Alfredo: Síntesis de Historia de la Iglesia. Baja Edad Media. Reforma y Contrarreforma (1303-1648), Madrid, Universidad Pontificia de Comillas, 1994. 
inusitado fervor. En las misiones evangelizadoras extraeuropeas destacó la labor de Francisco Javier en India y Japón, sin olvidar las actuaciones de otros religiosos en América ${ }^{6}$.

Los establecimientos crecieron en número y se expandieron, así en 1556 se constataba su presencia en Italia, España, Portugal, Francia, Alemania, Brasil, India o Japón. Incluso el quinto general, Claudio Aquaviva ${ }^{7}$, puso freno a este proceso y aceptó sólo aquellas fundaciones más seguras en el aspecto económico y más ventajosas en el apostólico. Las primeras fundaciones españoles se realizaron en Alcalá de Henares (1543), Valencia (1544) y Gandía (1545), extendiéndose rápidamente por toda la península ${ }^{8}$. En 1553 el P. Nadal dividió la asistencia de España en tres provincias: Andalucía o Bética ${ }^{9}$, Castilla y Aragón; y en 1574 se añadió la de Toledo.

La Compañía de Jesús se preocupó por su propia “historia”, aunque no fue hasta el generalato de Aquaviva cuando se encargó una "oficial”, labor que recayó en el florentino Nicolás Orlandini. Para realizar con éxito este plan, se ordenó recopilar los datos de cada una de las asistencias, de ahí la proliferación de los relatos provinciales, en forma de anales, donde se describían los aspectos más destacados de la vida cotidiana de sus colegios. En Roma se impuso un régimen centralizado y allí llegaba toda la información, con una duración cuatrimestral o anual, de las casas y de los misioneros. Toda esta documentación se encuentra repartida, destacando por su importancia el Archivo Romano, depósito central, complementándose con los depósitos provinciales ${ }^{10}$. El de Toledo se encuentra en una residencia de Alcalá de Henares y allí es donde se conservan varias historias de colegios, como las de Marchena ${ }^{11}$, Plasencia ${ }^{12} \mathrm{y}$, sobre todo,

6 BURRIEZA SÁNCHEZ, Javier: Jesuitas en Indias: entre la utopía y el conflicto: trabajos y misiones de la Compañía de Jesús en la América Moderna, Valladolid, Universidad de Valladolid, 2007 y SANTOS HERNÁNDEZ, Ángel: Los jesuitas en América, Madrid, Mapfre, 1992.

7 Antes le habían sucedido los siguientes generales: Ignacio de Loyola (1540-1556), Diego Laínez (15581565), Francisco de Borja (1565-1572), Everardo Mercuriano (1573-1580). El napolitano Claudio Aquaviva ocupó el cargo entre 1581 y 1615.

8 Las casas se establecían en las capitales de los antiguos reinos, en algunas ciudades con sede episcopal, en centros de particular importancia comercial (Medina del Campo) o marítima (Sevilla o Cádiz). BATLLORI, M.: "Los primeros colegios de los jesuitas en España” en DELGADO CRIADO, B. (coord.): Historia de la educación en España y América. La educación en la España Moderna (siglos XVI-XVIII), Madrid, Fundación Santa María, 1993, pp. 74-79.

9 La provincia de Andalucía constituía el lazo que unía las provincias americanas con las de Europa. SOTO ARTUÑEDO, Wenceslao (ed.): Los jesuitas en Andalucía: estudios conmemorativos del 450 aniversario de la fundación de la Provincia, Granada, Universidad de Granada, 2007.

10 VERDOY, Alfredo: “Los jesuitas en la Historia. Un balance bibliográfico provisional” en Historia 16, nº 363, (Julio 2006), pp. 30-43.

11 Historia del origen y fundación del Colegio de Marchena, de la Compañía de Jesús (1553 a 1766), A.P.T.S.I., C-200 (1564). El análisis de este documento ha dado lugar a una monografía, LOZANO NAVARRO, Julián José: La compañía de Jesús en el estado de los Duques de Arcos: el Colegio de Marchena (Siglos XVI-XVIII), Granada, Universidad de Granada, 2002. También del mismo autor: La Compañía de Jesús y el poder en la España de los Austrias, Madrid, Cátedra, 2005.

12 Historia del Colegio de Plasencia de la Compañía de Jesús escrita por el Padre Jerónimo de la Higuera de la misma Compañía, 1600, A.P.T.S.I, C-222. En relación con esta casa, destaca el trabajo de MARÍN BARRIGUETE, Fermín: “La fundación del Colegio de los jesuitas de Plasencia (1554-1562)” en Actas del Congreso Internacional Felipe II y las Artes, Madrid, Departamento de Historia del Arte II (Moderno) de la UCM, 2000, pp. 43-56. 
Carmona $^{13}$. Las personas encargadas de escribirlas fueron los rectores, padres superiores y directores de los establecimientos, o bien fueron encomendadas a otros padres.

La copia manuscrita encuadernada de Carmona (340 x $230 \mathrm{~mm}$ ) consta de 215 folios escritos por ambas caras. Se divide en dos partes, la primera realizada por el P. Juan Bautista de Algaba se extiende hasta el folio 78 vuelto; y la segunda, escrita por varios rectores posteriores, llega hasta el folio 215, se inicia en 1664 y finaliza en 1754. Cada una consta de varios capítulos, que recogen los acontecimientos más destacados sucedidos durante el trienio que cada superior gobernó. Aunque el título del documento señala como autor al P. Algaba, sabemos que fue el decimotercer rector, durante 1661 y 1664, iniciando el relato de forma retrospectiva de los primeros cuarenta y cinco años. Estas narraciones tenían unos objetivos, daban a conocer las vivencias y vicisitudes acontecidas, pero también poseían un carácter ejemplarizante y pedagógico, con la descripción sucesiva de las vidas de los religiosos más destacados, modelos de conducta a imitar. Así lo argumentaba el P. Algaba, quién refiriéndose a su estilo decía que era “como de narración religiosa, que no pretende curiosidad ni deleite, sino enseñanza y edificación de jesuitas”14.

La Historia del Colegio, citada en varios trabajos ${ }^{15}$, es la principal y casi única fuente sobre la casa, ya que en el Archivo Histórico Nacional apenas existe información sobre ella ${ }^{16}$. Carmona Domínguez, archivero de la ciudad, señala que su descripción se la facilitó D. Julián López García, responsable del Archivo de la Provincia Jesuita de Toledo ${ }^{17}$; también se empleó en un breve artículo sobre la iglesia de San Teodomiro de la Compañía de Jesús ${ }^{18}$ y sobre la presencia de los jesuitas en Carmona ${ }^{19}$. Sin embargo, a pesar de ser una fuente citada no tenemos ningún estudio en profundidad que nos muestre la rica información que contiene, que esperamos subsanar en parte con la publicación de varios trabajos.

Los numerosos estudios históricos sobre Carmona, dedicados a la etapa de la Prehistoria, Historia Antigua (época romana) e incluso Medieval, mediante el análisis funda-

13 Historia del Colegio de Carmona (Agosto de 1620 a 1754) escrita por el P. Juan B $B^{a}$ de Algaba, A.P.T.S.I., C-198 (126). Fruto del análisis de este manuscrito fue la publicación del siguiente artículo monográfico: PIZARRO ALCALDE, Felipe: "El Colegio de San Teodomiro de la Compañía de Jesús en Carmona (16191767)" en Carel. Revista de Estudios Locales, ${ }^{\circ} 6$ (2008), pp. 2.583-2.672. Puede consultarse en formato "pdf" www.museociudad.carmona.org/1museo/carel.htm.

14 Historia del Colegio de Carmona (Agosto de 1620 a 1754) escrita por el P. Juan Ba de Algaba, A.P.T.S.I., C-198 (126), f. 2 v.

15 GONZÁLEZ ISIDORO, José: “II. Memoria de los edificios” en Carmona, ciudad y monumentos, Carmona, S \& C, 1993, pp. 148-154; y HERNÁNDEZ DÍAZ, José, SANCHO CORBACHO, Antonio y COLLANTES DE TERÁN, Francisco: Catálogo arqueológico y artístico de la Provincia de Sevilla, tomo II, Sevilla, Diputación Provincial de Sevilla, 1943, pp. 169 y 259-260.

16 GUGLIERI NAVARRO, Araceli: Documentos de la Compañía de Jesús en el Archivo Histórico Nacional, Madrid, Razón y Fe, 1967.

17 CARMONA DOMÍNGUEZ, José María: "Bibliografía General de Carmona. Manuscritos, partituras manuscritas y tesis universitarias” en Carel. Revista de Estudios Locales, nº 2 (2004), p. 924.

18 MARTÍN PRADAS, Antonio y CARRASCO GÓMEZ, Inmaculada: "La Iglesia del Colegio de San Teodomiro de la Compañía de Jesús en la ciudad de Carmona: 1619-1754” en Laboratorio de Arte, nº 11 (1998), pp. 521-538.

19 GARCÍA GUTIÉRREZ, Fernando: “La Compañía de Jesús y Carmona (Sevilla)” en Estela. Revista Cultural e Informativa de Carmona, 2005, pp. 8-9. 
mentalmente arqueológico, muestran la importancia que tuvo en los orígenes de la cultura de la Baja Andalucía, lo que contrasta con la escasez de trabajos dedicados a la Edad Moderna $^{20}$. Las noticias de Carmona se encuentran desperdigadas por libros y manuscritos, destacando el libro coordinado por Pedro Romero Solís Carmona. Historia, cultura y espiritualidad $^{21}$. Las tres fuentes locales empleadas para el estudio de los siglos modernos son las del padre franciscano Juan Salvador Baptista de Arellano ${ }^{22}$, el manuscrito anónimo titulado El Curioso Carmonense (1787) ${ }^{23}$ y la de Manuel López Fernández (1886) ${ }^{24}$.

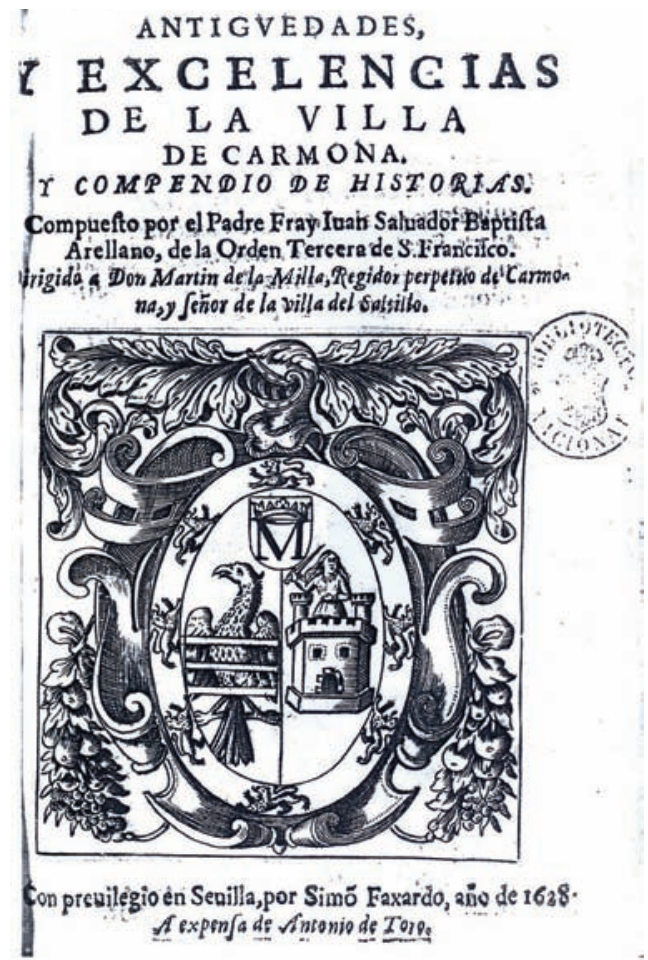

20 "[...] quizás sea este siglo, junto con la época visigoda, uno de los menos investigados, excepto en el aspecto artístico”, en HERRERA GARCÍA, Antonio y BALLESTER SALGUERO, José Ramón: Breve Historia de Carmona, Málaga, Sarriá, 2002, p. 62. Una excepción la constituyen los trabajos de Mira Caballos, especialmente MIRA CABALLOS, Esteban y VILLA NOGALES, Fernando de la: Carmona en la Edad Moderna: religiosidad y arte, población y emigración a América, Sevilla, Muñoz Moya, 1999.

21 ROMERO DE SOLÍS, Pedro (ed.): Carmona. Historia, cultura y espiritualidad, Sevilla, Ayuntamiento de Carmona, 1997.

22 ARELLANO, Juan Salvador Baptista de: Antigüedades y excelencias de la villa de Carmona, y compendio de historias, Sevilla, 1628, B.N. 2/41176.

23 La obra del padre Arellano es ampliada en el siglo siguiente. La Historia de Carmona que en el año de 1628 escribió el P. Fr. Juan Baptista de Arellano se divide en diez mapas para mayor diversión de los curiosos con algunas notas, y adicciones, y se continua hasta el presente año de 1787 por el Curioso Carmonense, Carmona, 1787 (editado por Antonio Lería, Carmona, 1997), I.H. (CSIC) F.A. G-374.

24 FERNÁNDEZ LÓPEZ, Manuel: Historia de la Ciudad de Carmona, Sevilla, 1886, B.N. 2/7682.

25 Se trata de la primera historia impresa de la ciudad (1628) y su relato llega hasta los Reyes Católicos. La historia está dirigida a don Martín de la Milla, regidor perpetuo de Carmona y señor de la villa del Saltillo. 


\section{La sociedad}

El grupo dirigente se concentró en torno a los oficios del concejo ${ }^{26}$ y se constituyó la oligarquía urbana. Allí se encuentran los apellidos más destacados como los Caro, Cansino, Quintanilla, Tamariz, Andino, Barba, Rueda, Villalobos, de la Milla o Góngora ${ }^{27}$. Entre los oficiales del cabildo estaban los alcaldes mayores, regidores, jurados o escribanos, formando un grupo cerrado, con estrechas conexiones familiares, cuyo principal privilegio residía en la exención en el pago de impuestos. Será la pertenencia a este grupo, y no la posesión de la hidalguía, la que asegurará la pertenencia al grupo dominante.

El estudio de esta oligarquía se realizará a través de la figura de Don Pedro de Hoyos y Escamilla ${ }^{28}$. Su padre se llamaba Francisco de Hoyos y su madre Isabel del Alcázar; sus abuelos fueron Francisco de Hoyos y Leonor de Escamilla, todos naturales de Carmona y de reconocido linaje $\mathrm{e}^{29}$. Se casó con doña Polonia Barba, original de Baeza, no tuvieron descendencia. Se sabe que tuvo al menos dos hermanos, el jesuita Juan y Jerónimo. Don Pedro ocupó el cargo de escribano público y del número del cabildo, siguiendo una tradición familiar que se remontaba a mediados del siglo $\mathrm{XV}^{30}$. Este oficio contaba con una buena retribución económica, ya que además del salario anual percibía un porcentaje de las multas, y podía manipular en su provecho los bienes de propios ${ }^{31}$, aunque la fuente que analizamos, como no podía ser menos, señala que su trabajo lo realizó con toda dignidad ${ }^{32}$. La importancia de saber leer y escribir le confería un estatus social elevado. Lo cierto es que el linaje de los Hoyos fue creciendo en importancia, acumuló una gran fortuna y se mezcló con los más importantes de la ciudad.

26 GONZÁLEZ JIMÉNEZ, Manuel: El concejo de Carmona a fines de Edad Media (1464-1523), Sevilla, Diputación Provincial de Sevilla, 1973.

27 SÁNCHEZ SAUS, Rafael: “Caballeros y Oligarcas en la Carmona medieval: Formación, desarrollo y límites de un grupo social” en Actas del I Congreso de Historia de Carmona. Edad Media, Sevilla, Ayuntamiento de Carmona, 1998, pp. 479-499.

28 PIZARRO ALCALDE, Felipe: "Don Pedro de Hoyos y Escamilla: un oligarca carmonense en el Siglo de Oro” en Estela. Revista Cultural e Informativa de Carmona (en prensa).

29 El P. Algaba señalaba lo siguiente: “[...] apellido en esta ciudad tan antiguo como ilustre; y que en los abuelos de nuestro difunto se halla enlazado con los Tamarices, Andinos, Barbas y Ruedas, con quien tenía parentesco..." en Historia del Colegio de Carmona (Agosto de 1620 a 1754) escrita por el P. Juan Ba de Algaba, A.P.T.S.I., C-198 (126), f. 188 r.

30 Hay varios documentos que lo confirman. En primer lugar, hay un testimonio firmado por el escribano del cabildo Fernando de Hoyos en 1467. En segundo lugar, el cabildo nombra escribano público del número a Fernando de Hoyos en 1481. Este cargo lo ocupa Francisco de Hoyos en 1481. En tercer lugar, Fernando de Hoyos pide al cabildo que nombre para ocupar su oficio a Paulo de Hoyos, su hijo, en quien renuncia en 1497. Por último, Gómez de Hoyos, escribano público, renuncia por enfermedad con la condición que se designe a su hijo Francisco de Hoyos, en 1504. En GONZÁLEZ JIMÉNEZ, Manuel: Archivo Municipal de Carmona: Catálogo de documentación medieval del Archivo Municipal de Carmona-I (1249-1474), Sevilla, 1976, p. 104, Doc. 385; y Archivo Municipal de Carmona: Catálogo de documentación medieval del Archivo Municipal de Carmona-II (1475-1504), Sevilla, 1981, Documentos 222, 1070, 1129 y 1936.

31 Concesión de pozos y aguas concejiles, arrendamientos de tierras o rentas del concejo en condiciones ventajosas.

32 La Historia del Colegio alaba en todo momento las actuaciones de su fundador, llegando a poseer rasgos y cualidades propias de los más importantes y ejemplares jesuitas. 
Don Pedro poseía varias casas en la plaza del Arrabal o Baja, entre las calles de San Francisco y de En Medio; y otras entre las de Sevilla y de En Medio ${ }^{33}$, además de otras propiedades y tierras. El escribano, resignado a no tener descendencia, quiso mostrarse ante sus vecinos como un hombre cristiano y generoso y emplear parte de su hacienda en paliar algunos de los males que afligían a los carmonenses. Daba limosna frecuentemente y socorría con alimentos, sobre todo pan, y con el vestido a los más necesitados. Decidió fundar, junto con su mujer, un colegio de jesuitas en Carmona en 1619. La Compañía de Jesús ya había alcanzado una gran popularidad por sus predicaciones durante las misiones populares y la educación a través de las fundaciones de colegios, y se había instalado en numerosas localidades de la provincia de Andalucía. Varias órdenes religiosas ambicionaban la hacienda de Don Pedro, que finalmente se inclinó hacía los jesuitas. Una de las misiones, llegada desde el colegio de Marchena, resultó decisiva ${ }^{34}$, y disipó las dudas del carmonense ${ }^{35}$.

La fundación se dotó mediante tres escrituras. En la primera se dejaron 260 aranzadas de olivar, varios pedazos de tierra calma, un molino, un caserío en la Atalaya ${ }^{36}$, dos "hazás" de tierra, varias casas principales, un pinar con sus pertenencias y 7.000 ducados. La segunda escritura aumentó la dote inicial con 16.000 ducados. Hubo una tercer documento, entregando el tributo de 440 reales de principal y 200 de réditos contra Andrés Martín de Madrigal, además de donar unas casas que tenía en la calle de En Medio. Todos estos bienes serían del colegio en propiedad, no pudiéndose vender ni enajenar.

33 Estos edificios se pueden ver en el mapa que recoge GONZÁLEZ JIMÉNEZ, Manuel: El concejo de Carmona..., p. 35.

34 Fundado por los duques de Arcos en 1567. LOZANO NAVARRO, Julián José: La compañía de Jesús en el estado..., p. 149.

35 Estas son las palabras que le dijo Don Pedro a su consejero:

“[...] buenos hombres son ellos, Pedro Sánchez, buena gente es esta: mi hacienda quiero darles y fundarles un convento, donde confiesen, prediquen y enseñen en virtud y letras y a los muchachos; estos son la semilla de la República; si se crían bellacos, bellacos se quedan; y si son bien criados hacen buenas Repúblicas”.

Historia del Colegio de Carmona (Agosto de 1620 a 1754) escrita por el P. Juan Ba de Algaba, A.P.T.S.I., C-198 (126), f. 11 v.

36 www.haciendaatalaya.com/historia.htm. Esta página web ofrece una información más amplia sobre este lugar. A partir de este momento la Compañía de Jesús se dedicó a explotar la nueva posesión. En 1622 se construyó una capilla dedicada a San Juan, acabándose de perfeccionar siete años después, cuando se colocó un retablo y se decoró al fresco el interior de la misma. Tras la confiscación de los bienes por parte del gobierno la Hacienda Atalaya Alta, al igual que otras propiedades fue puesta a la venta, pasando a manos privadas en la siguiente década. Los autores de esta información son Antonio Martín Pradas (Doctor en Historia del Arte) e Inmaculada Carrasco Gómez (Arqueóloga e Historiadora). 


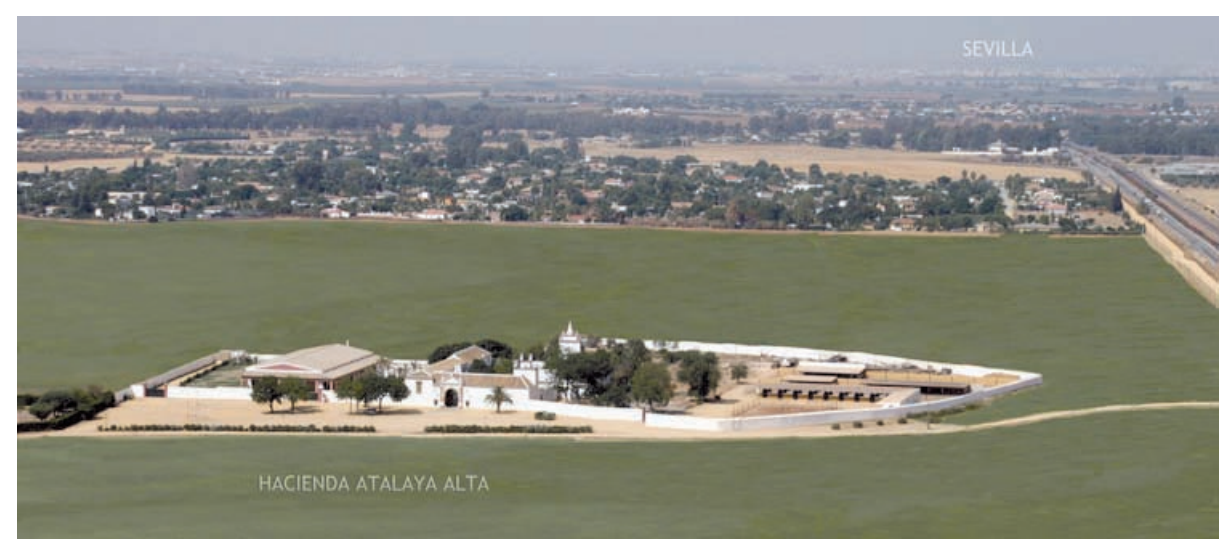

Imagen 2. Vista actual de la Hacienda Atalaya Alta.

Fuente: www.haciendaatalaya.com/historia.htm

La Compañía de Jesús, a través del Provincial de Andalucía, se obligaba a edificar una iglesia, un colegio y una casa para veinte religiosos, además de dos escuelas de gramática, “debiendo enseñarla gratis, a todos los que quisiesen concurrir”37. Don Pedro de Hoyos y sus descendientes quedarían como patronos, sólo él y los que dejase nombrados podrían enterrarse en la capilla Mayor de la iglesia. La fiesta anual perpetua se celebraría el día de San Teodomiro, dando al patrono la vela según la costumbre, y se oficiarían por su alma las misas que se hacían a los patronos ${ }^{38}$. Además, ordenó que únicamente se colocase el escudo de su linaje en el panteón.

Don Pedro y su mujer fundaron una obra pía para casar doncellas pobres, vecinas de Carmona. Para este fin se pusieron a disposición un pinar, siete tiendas, siete mesones y nueve casas. Todas estas posesiones, menos el pinar, estaban situadas en la plaza del Arrabal y en la calle de Sevilla, valorándose en 24.000 ducados. Las dotes anuales se darían a quince doncellas, ascendiendo su valor a 20.000 maravedíes. El día de San Teodomiro debían estar casadas e ir a la iglesia jesuita con su marido para recibir públicamente la limosna.

¿Qué buscaba el patrono del colegio y la obra pía? En principio, admiración, fama, honor, estima o popularidad; pero también existía un interés económico. El puesto no carecía de importancia, como lo demuestra la lucha que se produce en 1638, al enfrentarse dos familias, los Vargas y los Villalobos ${ }^{39}$. En los primeros momentos, el rector y el patrono del colegio elegían la mitad de las doncellas y por ello el segundo recibía diez mil maravedíes. Posteriormente, se decidió ofrecer la dotación "por suerte” antes los problemas ocasionados en las elecciones. El cargo se llegó a vender en dos ocasiones, siendo comprado finalmente por el propio colegio en 1719. Desde este momento el Padre Provincial de Andalucía será el patrono del mismo.

Doña Polonia falleció antes que su marido, que no volvió a contraer matrimonio y se dedicó a finalizar los proyectos de ambos. Durante el transcurso de su enfermedad, los

37 Historia del Colegio de Carmona (Agosto de 1620 a 1754) escrita por el P. Juan B ${ }^{a}$ de Algaba, A.P.T.S.I., C-198 (126), f. 407 r.

38 Ibídem, ff. 407 v.-408 r.

39 PIZARRO ALCALDE, Felipe: “El Colegio de San Teodomiro...”, pp. 2.628-2629. 
religiosos le acompañaron y auxiliaron, falleciendo el domingo 3 de mayo de 1620 . Al entierro acudieron las personas más importantes de la ciudad, grandes señores, miembros del cabildo y religiosos, además de dos cofradías y las tres comunidades de Santo Domingo, San Francisco y el Carmen. Transcurrió por el Arrabal y la plaza Baja, pasó por las parroquias de San Pedro y San Bartolomé hasta San Salvador, en la plaza Alta. Después la clerecía hizo sus vigilias y se dijeron misas cantadas de cuerpo presente. Se hizo lo mismo en todos los conventos: Madre de Dios, Santa Clara, Santa Catalina y la Concepción. Pronto se hicieron las honras y un gran túmulo y el cuerpo del difunto se depositó en la capilla de Santo Tomé en la iglesia de San Salvador, lugar de enterramiento de los Hoyos, al no haberse edificado la iglesia del colegio. En el funeral y en el entierro se gastaron 3.400 maravedíes. Sus restos se trasladaron al templo de la Compañía en $1623^{40}$.

El grupo numéricamente más importante lo formaban los jornaleros del campo, ya que la mitad de los carmonenses subsistían como temporeros al tratarse de una villa fundamentalmente agrícola. Las tierras de la Vega se conocían por el buen pan que producían. En mejor situación se encontraban los artesanos que, en general, cubrían las necesidades del mercado interno y suministraban a la población los productos básicos de uso doméstico y las herramientas agrícolas o de albañilería. En el sector terciario se incluían desde los lacayos en el estrato más bajo, hasta los médicos y procuradores. También era llamativo el porcentaje de la población no activa (clérigos o rentistas).

La sociedad carmonense no se vio libre de una población marginal, los pobres y las prostitutas. Las denuncias y quejas sobre su excesivo número, al igual que sucedía en la mayor parte de las ciudades, no sólo de la Monarquía Hispánica sino europeas, fue una constante ${ }^{41}$. Este hecho queda constatado a través de dos actuaciones: la labor del fundador y el trabajo de los jesuitas. Don Pedro suministraba frecuentes limosnas a los más necesitados y socorría cotidianamente proporcionándoles pan. También les regalaba ropa, medias, jubones, calzones, ropillas y zapatos, que entregaba a Pedro Sánchez Ponce para que lo repartiese entre los niños pobres de las parroquias. Los jesuitas también se emplearon en este ministerio, suministraban limosna a los necesitados en la puerta del colegio y aprovechaban la oportunidad para enseñarles la doctrina cristiana²; también llevaban directamente la limosna la casa de los pobres vergonzantes, que no quería salir para no mostrar públicamente su situación.

La asistencia hospitalaria y sanitaria continuaba estando en manos de la Iglesia en el siglo XVII. Los poderes públicos, a menos que se produjera una epidemia que pusiera en peligro la vida de todos, rara vez se ocupaban de este problema. La Iglesia y los

40 Historia del Colegio de Carmona (Agosto de 1620 a 1754) escrita por el P. Juan Ba de Algaba, A.P.T.S.I., C-198 (126), f. 12 r.

41 MAZA ZORRILLA, Elena: Pobreza y asistencia social en España, siglos XVI al XX. Aproximación histórica, Valladolid, Universidad de Valladolid, 1987.

42 En la Historia aparecen varios ejemplos de esta situación:

"Estableciose enseñar por semanas todos los días la doctrina cristiana a los pobres de porte-

ría, antes de darles la limosna a medio día e ir todos los días de Cuaresma a las parroquias

a enseñarla. Todos los domingos segundos del mes inmediatos al del jubileo, que es el domingo tercero, se dispuso fuese un padre a hacer plática a la plaza del Arrabal y para en los domingos siguientes cuartos del mes, se renovó el uso algún tiempo interrumpido de hacer plática de doctrina cristiana”.

Historia del Colegio de Carmona (Agosto de 1620 a 1754) escrita por el P. Juan Ba de Algaba, A.P.T.S.I., C-198 (126), ff. 75 v.-76 r. 
vecinos generosos eran los únicos encargados de atender a pobres y enfermos. Los hospitales poseían, para atender a sus fines asistenciales y piadosos, bienes consistentes en olivares, viñas, tierras de labor, casas y tributos; aunque la mayor parte de sus ingresos procedían de limosnas y mandas testamentarias. Los hospitales y cofradías desempeñaron una función social benemérita, especialmente en los años de carestía o epidemia ${ }^{43}$.

En cuanto a las prostitutas hay menos información, aunque sí advertimos que la fundación de la obra pía está muy relacionada con esta situación. El patronato estaba destinado a casar doncellas pobres y vecinas de Carmona ${ }^{44}$, por contar la ciudad con numerosas mujeres necesitadas, que estaban en riesgo de "perder la honestidad” por su pobreza y ofender a Dios.

\section{La demografía y la economía}

El P. Algaba nos proporciona una cifra sobre el número de habitantes de Carmona a mediados del siglo XVII: "tres mil vecinos" 45 . Este dato viene a añadirse a los trabajos demográficos más exhaustivos sobre la localidad, como el de Cruz Villalón, quién señala que a mediados del siglo XVIII la ciudad reunía a más de 3.100 vecinos (12.000 habitantes aproximadamente), situándose entre las quince ciudades más importantes de reino de Sevilla ${ }^{46}$. El rey Felipe IV visitó la ciudad en 1624 y se alojó en un palacio ubicado en la periferia de Levante porque la residencia real, el Alcázar, no estaba en condiciones para recibir a un monarca. El 27 de marzo de 1630, previo pago de cuarenta mil ducados, Carmona obtuvo el título de Ciudad y preparó el apogeo del caserío en el siglo XVIII, manifestándose visualmente a través de la construcción de numerosos palacios, iglesias y conventos ${ }^{47}$.

Desde el punto de vista económico predominaba la agricultura, junto con la ganadería, constituyéndose en un enclave estratégico ${ }^{48}$. Varios factores ponían en peligro las cosechas de los jornaleros: sequías, lluvias torrenciales o plagas de langosta, y se

43 GONZÁLEZ JIMÉNEZ, Manuel: El concejo de Carmona..., pp. 113-115.

44 Aunque el P. Algaba no lo señala, Archimbaud añade también la condición de huérfanas. Fundaciones de los Regulares expulsos. Provincia de Andalucía por Don Juan Antonio Archimbaud, Tomo II., A.P.T.S.I., C-193(2), f. $408 \mathrm{v}$.

45 Historia del Colegio de Carmona (Agosto de 1620 a 1754) escrita por el P. Juan Ba de Algaba, A.P.T.S.I., C-198 (126), f. 33 r.

46 Cruz Villalón utiliza como principal fuente el Vecindario de Ensenada, elaborado en 1759 a partir de los datos del Libro de los cabezas de casa, que da para Carmona 3.081 vecinos seglares y 112 eclesiásticos, en CRUZ VILLALÓN, Josefina: Carmona 1751: según las Respuestas Generales del catastro de Ensenada, Madrid, Centro de Gestión Catastral y Cooperación Tributaria, 1990, p. 7. Sobre la demografía de la ciudad, véase: MIRA CABALLOS, Esteban: La población en Carmona en la segunda mitad del siglo XVIII, Carmona, Carmograf, 1994 y MONTAÑO REQUENA, María Isabel: "La población de Carmona en las series parroquiales: siglos XVI-XIX” en Archivo Hispalense n 213 (1987), pp. 93-112.

47 JiMÉnEZ MARTÍN, Alfonso: La Puerta de Sevilla en Carmona, Málaga, Consejería de Obras Públicas y Transporte (Secretaría General Técnica), 1989, p. 84.

48 El Padre Algaba la describe así:

“[...] la ciudad de Carmona (antigua, noble, y rica) a quien el P. Juan de Mariana en su Historia

de España nombra Sanctissimun Betice Municipium, riquísimo y abundantísimo lugar fuerte de

Andalucía [...]”.

Historia del Colegio de Carmona (Agosto de 1620 a 1754) escrita por el P. Juan Ba de Algaba, A.P.T.S.I., C-198 (126), f. 4 r. 
trataba de combatirlos mediante misas, rogativas y procesiones ${ }^{49}$. Las crisis de mortalidad fueron una constante en las sociedades de aquella época ${ }^{50}$ y la población estuvo expuesta a períodos críticos, como la epidemia de peste de 1649 y 1650 o de tercianas en $1786^{51}$.

Los años de peste que padeció Andalucía, en general, y Carmona, en particular, ocasionaron una pérdida de población muy significativa. Uno destacó sobre los demás: 1649. Aunque algunas naves de mercaderes habían traído los gérmenes, no apareció el mal en toda su crudeza hasta que se desbordó el río Guadalquivir y convirtió toda Sevilla en un inmenso barrizal. Por mucho que se sacrificaron las órdenes religiosas, no fue posible atender a tantos enfermos, y el dar rápida sepultura a los cadáveres, abandonados en los patios y huertas, se estableció como primer objetivo ${ }^{52}$.

Un ministerio que San Ignacio enseñó a sus compañeros fue la visita a los hospitales $^{53}$. Más que las actuaciones llevadas a cabo en tiempos normales, el sacrificio de sus vidas en las frecuentes pestilencias proporcionó a los jesuitas estima y veneración, produciéndose en numerosas ocasiones su propio contagio. Desde el noviciado o las casas de Tercera Probación ${ }^{54}$ los regulares se ejercitaban en algunos de los ministerios apostólicos y cuando se tenía información de que la epidemia había llegado al lugar, se consagraban al servicio de los enfermos. La actuación de los religiosos del colegio de Carmona, no sólo en la su propia ciudad, sino enviando ayuda a Sevilla fue importan-

49 En la Historia aparecen descritas estas procesiones:

"Los de la Compañía que en Carmona quedaron acudieron fervorosos dentro y fuera de casa a los apestados; hicieron una grave y devota y numerosa procesión que salió de nuestra iglesia y pasó lo más principal de la ciudad. Iban en ella nuestros estudiantes llevando delante un hermoso niño Jesús y cerraba la procesión una bellísima imagen de Nuestra Señora, que vistieron con primor las religiosas dominicas del convento de Madre de Dios, acompañando a Hijo y Madre además de nuestras escuelas toda la clerecía y nobleza de Carmona, cantando la Letanía de la Santísima Virgen, acción que pareció muy bien y enterneció devotamente los corazones de todos”.

Historia del Colegio de Carmona (Agosto de 1620 a 1754) escrita por el P. Juan Ba de Algaba, A.P.T.S.I., C-198 (126), f. 62 r.

50 ALVAR EZQUERRA, Alfredo: Demografía y sociedad en la España de los Austrias, Madrid, 1996.

51 Según Montaño Requena, que estudia las series parroquiales, la ciudad sufre dos crisis demográficas en el siglo XVII: la primera es más débil y ocurre entre 1637 y 1638, y la segunda es más profunda y se sitúa en torno a 1685. MONTAÑO REQUENA, María Isabel: op. cit., pp. 93-112.

52 En Carmona el hermano Manuel de Chaves se empleó duramente en este ministerio:

“[...] entrábase en las casas de los pobres ya solo, ya acompañado de otros que convidaba; amortajaba a los difuntos y llevaba a enterrar a la iglesia en sus brazos a los que tenía en desamparo su miserable estado y pobreza”.

Historia del Colegio de Carmona (Agosto de 1620 a 1754) escrita por el P. Juan Ba de Algaba, A.P.T.S.I., C-198 (126), f. 154 r.

53 BURRIEZA SÁNCHEZ, Javier y EGIDO, Teófanes: "La antigua Compañía de Jesús (siglos XVI-XVIII)” en T. EGIDO (coord.), Los jesuitas en España y en el mundo hispánico, Madrid, Marcial Pons, 2004, pp. 145-147.

54 En 1643 los padres de Tercera Probación, que se encontraban en la casa profesa de Sevilla, pasaron al colegio de Carmona. Los sermones, confesiones, pláticas en plazas públicas, visitas a hospitales, cárcel y escuelas aumentaron. Estuvieron doce años, constituyendo un gasto importante para el colegio. 
tísima, sobre todo durante la peste de $1649^{55}$. Ese mismo año se celebró una procesión de penitencia con Nuestra Señora del Rosario, Señora Santa Ana, Santo Domingo Soriano y San Jacinto, con la asistencia del clero, la Ciudad y las cofradías. Aunque había numerosos hospitales, no todos cumplían los fines de su fundación. En 1615 se redujo su número y se unificaron los llamados Hospitales Generales, el de San Pedro ${ }^{56}$, para asistir y curar a los pobres enfermos, y el de Misericordia o Santa Caridad, para pobres convalecientes $^{57}$. El trabajo de los jesuitas fue constante y los gobernantes carmonenses reclamaron frecuentemente sus servicios ${ }^{58}$.

\section{La religiosidad}

Los primeros contactos entre los jesuitas y la población de Carmona se producen a principios del siglo XVII. La ciudad se dividía en siete colaciones parroquiales ${ }^{59}$, germen de los actuales barrios, y ya se constataba el crecimiento del clero, secular y regular, y la existencia de siete grandes parroquias, varias iglesias, ermitas ${ }^{60}$, monasterios y conventos, además de cofradías y hospitales. Por ello, al siglo anterior se le conoce

55 La casa profesa de Sevilla solicitó ayuda al colegio de Carmona:

“[...] pues no sólo el P. Rector acudió a la necesidad de Carmona, sino que envió socorro a los vecinos. Pidiolo la casa profesa de Sevilla hallándose falta de tantos y tan cristianos obreros como les robó la peste; y así los padres que en este colegio hacían la Tercera Probación, fueron el P. Estanislao de Acosta y P. Gabriel de Lima, y este trocó la vida temporal por la eterna en tan gloriosa demanda. Disuelta la Congregación Provincial de Sevilla al tercero día para que los padres rectores se fuesen a sus colegios antes que en los lugares se cerrase la entrada, se vino a nuestra heredad de la Atalaya el P. Provincial Fernando de Poblaciones con su compañero el P. Lorenzo de Salazar con determinación de estarse allí despacio despachando los negocios de la provincia. Llegados a ella hallaron herido de peste al hermano Jerónimo Sánchez y por huir del peligro se fueron al cortijo de Santa Marina cuya incomodidad obligó a dejarlo y se fueron a la oscurajosa heredad de nuestro colegio de Córdoba”.

Historia del Colegio de Carmona (Agosto de 1620 a 1754) escrita por el P. Juan Ba de Algaba, A.P.T.S.I., C-198 (126), ff. 61 v.-62 r.

56 Para conocer la evolución de la sanidad en la ciudad contamos con el siguiente estudio GÓMEZ MARTÍN, Ma del Carmen y LÓPEZ DÍAZ, María Teresa: El hospital de San Pedro (1615-1875): la evolución de la sanidad en Carmona, Carmona, 1997.

57 CRUZ VILLALÓN, Josefina: op. cit., p. 56 y JIMÉNEZ MARTIN, Alfonso: op. cit., pp. 67-70.

58 En la Historia son frecuentes estos relatos:

“A este tiempo pidió la ciudad un sacerdote que de día y de noche asistiese a los heridos del hospital que se puso en el Alcázar alto. Todos se ofrecieron a la empresa: hizo mayores instancias el P. Diego Serrano que a la razón leía cátedra de Mayores en este colegio y valiéronle para lograr su caridad y fervor apostólico. Fueron con otro sacerdote seglar el dicho hospital, donde vestido con una túnica de estertín, acudió en lo corporal de comida y cura, y en lo espiritual administración de sacramentos a los apestados todo el tiempo que los hubo. En él sucedieron cosas señaladas para gloria de Dios y salvación de las almas; una de ellas fue que vino al hospital una moza a quien Nuestro Señor con peste en el cuerpo para que con el Jordán del santo bautismo se limpiase como otro Noaman de la leprosa incredulidad de su alma. Sacole de su engaño el P. Serrano, instruyéndola en los misterios de nuestra santa fe y bautizada, sana en el alma escapó también de la enfermedad del cuerpo, y después vivió y murió como buena cristiana”.

Historia del Colegio de Carmona (Agosto de 1620 a 1754) escrita por el P. Juan Ba de Algaba, A.P.T.S.I., C-198 (126), f. 62 r.

59 Santa María, Santiago, San Salvador, San Felipe, San Bartolomé, San Blas y San Pedro.

60 San Mateo, San Antón o de Nuestra Señora del Real, Santa Lucía y Virgen de la Gracia. 
como el de las grandes fundaciones monásticas o de los conventos. La iglesia de San Pedro era la más importante si tenemos en cuenta el número de fieles que albergaba. El establecimiento de los jesuitas en 1619 en Carmona se considera tardío, ya que se habían establecido desde hacía tiempo en la provincia de Andalucía: Córdoba (1553), Sevilla (1554) ${ }^{61}$, Granada (1554), Cádiz (1564) ${ }^{62}$ o Marchena (1567) ${ }^{63}$, y además se habían instalado los franciscanos, jerónimo, dominicos y carmelitas.

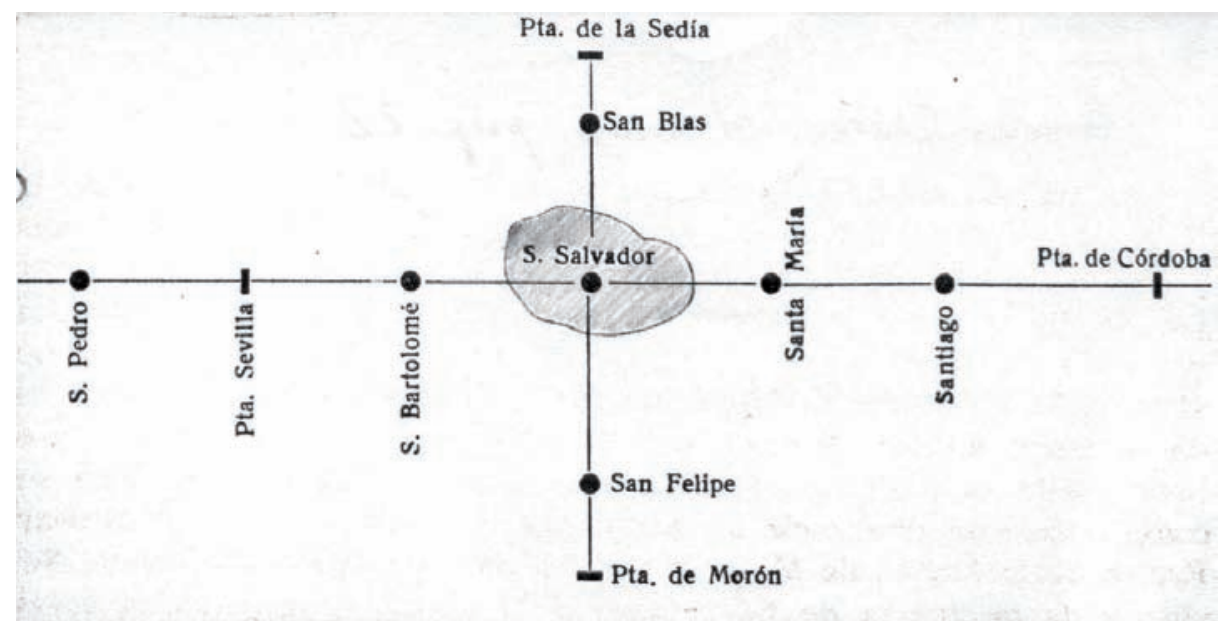

Imagen 3. Las siete colaciones de Carmona.

Fuente: CARMONA RUIZ, María A.: “La ganadería en Carmona durante la Baja Edad Media” en Actas del I Congreso de Historia de Carmona. Edad Media, Sevilla, Ayuntamiento de Carmona, 1998, p. 326.

61 HERRERA PURGA, Pedro: Los jesuitas en Sevilla en tiempo de Felipe II, Granada, Universidad, 1971. 62 AZCÁRATE, Isabel de: Los jesuitas en la política educativa del Ayuntamiento de Cádiz (1564-1767), Granada, Facultad de Teología, 1996.

63 Existe un índice con todas las fundaciones de los colegios de la Compañía de Jesús en España. MARTÍNEZ-ESCALERA, José: “Órdenes religiosas” en B. DELGADO CRIADO (coord.), Historia de la educación en España y América. La educación en la España Moderna (siglos XVI-XVIII), Madrid, Fundación Santa María, 1993, pp. 428-438 y PINEDO, Isidoro: “La expulsión de los jesuitas” en B. DELGADO CRIADO (coord.), Historia de la educación en España y América. La educación en la España Moderna (siglos XVI-XVIII), Madrid, Fundación Santa María, 1993, pp. 697-708. 


\begin{tabular}{|l|l|c||}
\hline \multicolumn{2}{|c|}{$\begin{array}{c}\text { CONVENTOS Y ÓRDENES RELIGIOSAS ESTABLECIDAS ANTES DE 1619 } \\
\text { Nombre }\end{array}$} & $\begin{array}{l}\text { Orden religiosa } \\
\text { Año de fundación }\end{array}$ \\
\hline Convento de Santa Clara & $\begin{array}{l}\text { Franciscanas } \\
\text { (Clarisas) }\end{array}$ & 1465 \\
\hline Convento de San Sebastián & Franciscanos & 1467 \\
\hline $\begin{array}{l}\text { Monasterio de Santa María de Gracia o de } \\
\text { Nuestra Señora de Gracia }\end{array}$ & Jerónimos & 1477 \\
\hline Convento de Santa Ana & Dominicos & 1505 \\
\hline Convento de Madre de Dios & Dominicas & 1512 \\
\hline $\begin{array}{l}\text { Convento de la Concepción o de Santa Isabel } \\
\text { de los Ángeles }\end{array}$ & Franciscanas & 1513 \\
\hline Convento de Nuestra Señora del Carmen & Carmelitas Descalzas & 1554 \\
\hline Convento de Santa Catalina de Siena & Dominicas & 1564 \\
\hline $\begin{array}{c}\text { CONVENTOS Y ÓRDENES RELIGIOSAS ESTABLECIDAS DESPUÉS DE 1619 } \\
\text { Colegio de San Teodomiro }\end{array}$ & Jesuitas & 1619 \\
\hline $\begin{array}{l}\text { Convento de la Santísima Trinidad o de las } \\
\text { Descalzas }\end{array}$ & $\begin{array}{l}\text { Agustinas recoletas } \\
\text { descalzas }\end{array}$ & 1629 \\
\hline Convento de los Carmelitas Descalzos & Carmelitas Descalzos & 1687 \\
\hline
\end{tabular}

Tabla 1. Conventos y órdenes religosas en Carmona (1465-1687) ${ }^{64}$

Fuente: Elaboración propia.

La presencia de los "hijos de San Ignacio" constituyó una novedad en la forma de entender la religiosidad y pronto se emplearon con tenacidad en los ministerios propios. Estos podían ser ejercidos en su casa e iglesia, donde enseñaban la doctrina cristiana a los niños y predicaban al pueblo, celebraban sus solemnidades, escuchaban a los penitentes a través de la confesión y repartían la sagrada comunión. Pero era necesario salir para atender a los presos de las cárceles, sentenciados a muerte, enfermos de los hospitales y recorrer los pueblos más alejados realizando misiones y buscar a los pecadores. En Carmona existía una preocupación especial por la instrucción de los más jóvenes y sabemos que el P. Luis Guerrero dedicó especial atención a la enseñanza del catecismo, empleando coplitas cantadas contra el pecado ${ }^{65}$.

64 Para elaborar la tabla se han consultado las siguientes obras: GONZÁLEZ JIMÉNEZ, Manuel: El concejo de Carmona...; JIMÉNEZ MARTIN, Alfonso: op. cit.; MIURA ANDRADE, José María: “Beatas, eremitas y monasterios de Carmona” en Actas del I Congreso de Historia de Carmona. Edad Media, Sevilla, Ayuntamiento de Carmona, 1998, pp. 565-583 y SÁNCHEZ HERRERO, José: “La iglesia y la religiosidad en Carmona durante la Baja Edad Media” en Actas del I Congreso de Historia de Carmona. Edad Media, Sevilla, Ayuntamiento de Carmona, 1998, pp. 415-455. Con motivo del entierro de un padre jesuita, el P. Algaba señala que: “Acudieron las cuatro religiones de Santo Domingo, San Francisco, el Carmen y San Jerónimo, que solas con nosotros hay en esta ciudad...”. Historia del Colegio de Carmona (Agosto de 1620 a 1754) escrita por el P. Juan $B^{a}$ de Algaba, A.P.T.S.I., C-198 (126), f. 41 r.

65 El jesuita, de avanzada edad, se ejercitaba en este ministerio de la siguiente manera:

“[...] y convocando a los niños de escuela, enseñándoles además de la doctrina, coplitas santas contra el pecado, persuadiéndoles las tuviesen de memoria y las cantasen; y era de notable edificación y ternura ver al santo viejo cercado de niños, dándoles el tono para cantarlos y repartiendo premios a quien mejor los decía, y sabía la doctrina”.

Historia del Colegio de Carmona (Agosto de 1620 a 1754) escrita por el P. Juan Ba de Algaba, A.P.T.S.I., C-198 (126), f. 14 v. 
Carmona tenía fuertes devociones arraigadas en el tiempo, como la Virgen de Gracia, San Mateo y San Teodomiro. La Compañía de Jesús participaba en ellas e introdujo las propias, San Ignacio de Loyola, San Francisco de Borja y San Francisco Javier, al igual que habían hecho las otras órdenes religiosas como Santo Domingo y la Virgen del Rosario para los dominicos, San Francisco para los franciscanos, la Virgen del Carmen para los carmelitas ${ }^{66}$. Así, el fundador de la Compañía intercedía favorablemente ante las frecuentes enfermedades y problemas del parto ${ }^{67}$ y así lo retrataron varios pintores como Rubens en Los milagros de San Ignacio. La veneración de la reliquias en España, como en el resto de la Europa católica, estuvo presente antes que las imágenes de los santos pasaran a ser objetos de devoción y el Concilio de Trento exigió estrictos procedimientos de certificación ${ }^{68}$. A los colegios llegaron objetos procedentes de Roma y Alemania y, más concretamente, el de Carmona recibió los de diferentes santos ${ }^{69}$. A estas reliquias se les atribuía la curación de enfermedades, como sucede con las de San Ignacio y San Francisco Javier.

La Virgen de Gracia se convirtió en la principal devoción y patrona de la ciudad ${ }^{70}$, superando el apoyo de Fernando III a Nuestra Señora del Real o el de los jesuitas a San Teodomiro $^{71}$. Las causas por las se buscaba su protección y amparo eran enfermedades de reyes, epidemias, guerras y otras calamidades públicas, aunque destacaban las rogati-

66 GONZÁLEZ ISIDORO, José: “Aproximación a un estudio iconológico de los ángeles, santos y alegorías en la ciudad de Carmona” en Carel. Revista de Estudios Locales, no 3 (2005), pp. 1105-1186.

67 En el manuscrito se relatan varios ejemplos:

"La devoción de nuestro padre San Ignacio creció mucho en este tiempo y especialmente en sus enfermedades, enviaban todos a casa por una reliquia suya que tenemos, y viéronse cosa al parecer milagrosa, entre ellos una mujer que tenía la criatura muerta en el vientre, mas hacía de tres días; estando ya casi moribunda, corrompida y hedionda, encomendose al santo, pidiendo su reliquia al punto, al punto se la aplicaron parió y libró del peligro”.

Historia del Colegio de Carmona (Agosto de 1620 a 1754) escrita por el P. Juan Ba de Algaba, A.P.T.S.I., C-198 (126), f. 33 r.

68 CHRISTIAN, William A.: Religiosidad local en la España de Felipe II, Madrid, Nerea, 1991.

69 El colegio consigue las reliquias de los mártires San Amancio y San Cayo:

"En su tiempo trajo de Roma varias e insignes reliquias con testimonio jurídico. El P. Juan de Casarrubios, prepósito de la casa profesa de Sevilla cuando fue por provincial de esta provincia a la congregación de procuradores y pidiéndole el P. Miguel Carbonel algunas reliquias que colocar en nuestra iglesia, le envió dos insignes que fueron la canilla de un brazo de San Amancio, mártir, y un pedazo grande de otra canilla más gruesa de San Cayo mártir, y el dicho P. Juan de Casarrubios justificó con juramento y firma suya ser las mismas que en Roma recibió el P. Juan Corbo, presbítero vecino de aquella ciudad como todo consta más largamente de testimonio auténtico y pasado por el ordinario, que se guarda en el archivo de este colegio".

Historia del Colegio de Carmona (Agosto de 1620 a 1754) escrita por el P. Juan Ba de Algaba, A.P.T.S.I., C-198 (126), f. 30 r.

70 CARMONA DOMÍNGUEZ, José María (dir.): La Virgen de Gracia de Carmona, Carmona, Hermandad de Nuestra Señora la Santísima Virgen de Gracia, 1990.

71 DOMínGUEZ ORTIZ, Antonio: “Prólogo” en J. Mª CARMONA DOMíNGUEZ, La Virgen de Gracia de Carmona, Carmona, Hermandad de Nuestra Señora la Santísima Virgen de Gracia, 1990, p. XIX. Actualmente han desaparecido o al menos han perdido participación popular toda una serie de fiestas de santos: San Sebastián, San Roque, San Matías, San Teodomiro, Santiago, San Marcos, San Miguel; o advocaciones a la Virgen: Concepción, Encarnación o Candelaria. RODRÍGUEZ BECERRA, Salvador: "Rituales festivos en torno a la Virgen de Gracia” en La Fiesta, la ceremonia, el rito, Coloquio Internacional de Granada, Granada, Universidad de Granada, 1990, pp.115-126. 
vas para evitar la pérdida de cosechas ante el exceso de lluvias y las frecuentes sequías. En 1737 se produce una larga sequía, ante lo que se hace subir a la Virgen desde su ermita a la ciudad para obtener el "milagro” de la lluvia. Si no se conseguía el efecto deseado, se achacaba a los pecados cometidos ${ }^{72}$. El número de devotos creció hasta convertirse a partir del siglo XIX y hasta el momento en el símbolo religioso más importante.

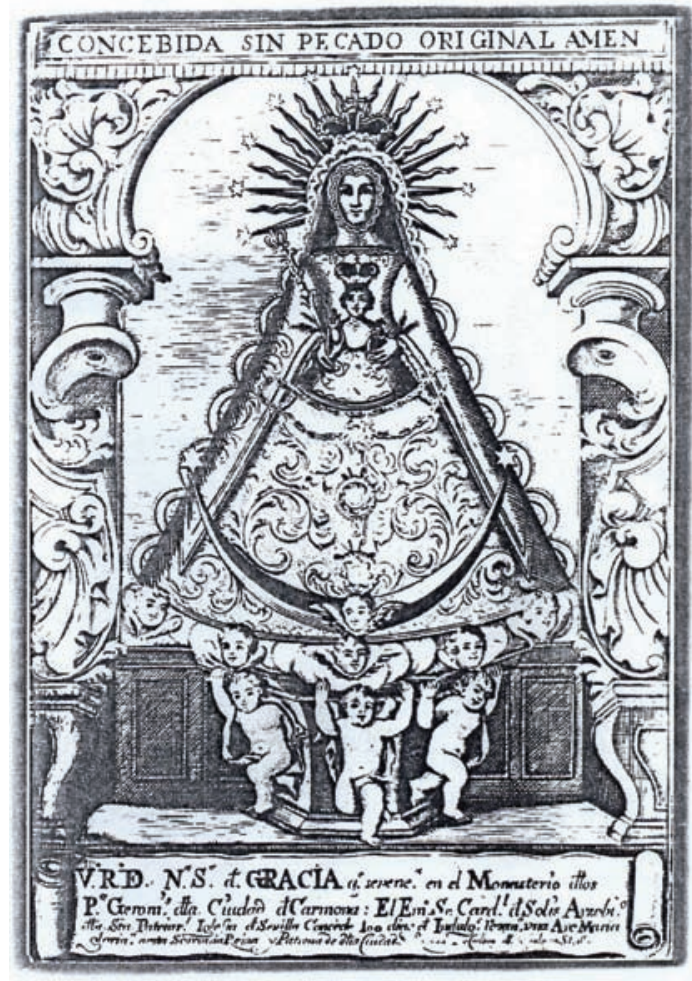

Imagen 4. La Virgen de Gracia.

Fuente: El Curioso Carmonense. La Historia de Carmona que en el año de 1628 escribió el P. Fr. Juan Baptista de Arellano se divide en diez mapas para mayor diversión de los $\mathrm{cu}$ riosos con algunas notas, y adicciones, y se continua hasta el presente año de 1787 por el Curioso Carmonense, Carmona, 1787, I.H. (CSIC) F.A. G-374, s/f.

El culto a San Mateo sobresale dentro del grupo devocional ligado al pueblo y a su historia, ya que en su día, 21 de septiembre, se conquistó la ciudad a los musulmanes. Una inscripción, colocada en la Puerta de Córdoba, recordaba la veneración otorgada tanto a él y a San Teodomiro ${ }^{73}$. El colegio jesuita colaboró de forma directa

72 Así lo relata la Historia:

"Este año de 37 fue muy estéril de todo por no haber llovido en cuatro meses, lo que obligó a esta ciudad a votar fiestas trayendo en procesión general a nuestra patrona María Santísima de Gracia a la iglesia Mayor. Se hizo un novenario muy solemne y al último día se trajo en procesión general también, a la iglesia Mayor devotísima imagen de Jesús Nazareno que se venera en la iglesia parroquial del Señor San Bartolomé. Por todo (por nuestros pecados) quedó sin efecto alguno; porque el cielo se mantuvo de bronce como hasta allí”.

Historia del Colegio de Carmona (Agosto de 1620 a 1754) escrita por el P. Juan Ba de Algaba, A.P.T.S.I., C-198 (126), f. 196 v.

73

"No me enorgullezco yo, Carmona, de encumbrarme hasta los cielos, ni en verme rodeada de fértil vega de trigo, ni en que el lucero me alumbre a caballo en la aurora, ni en la hidalguía de mis ciudadanos, sino feliz me alzo con el brillo de mis dos patronos, así Teodomiro como Mateo”.

Guía de Carmona, Madrid, Dirección General de Bellas Artes, 1966, p. 37. 
en este culto, como se ve reflejado claramente cuando la ciudad de Carmona envía una diputación en 1698 al rector del colegio, el P. Sebastián de Biedma, pidiéndole permiso para celebrar en su iglesia la fiesta de San Mateo.

Cuando los jesuitas llegan, el culto a San Teodomiro ya ocupaba uno de los primeros lugares en la religiosidad de la población. Según la tradición era natural de la ciudad, profesó como monje benito y fue sacrificado en tiempos de Abderramán II en Córdoba. En aquella época era frecuente que se degollase a los cristianos, de ahí que se le represente como un hombre vestido con hábito benedictino con un corte en el cuello, a veces con la espada clavada, palma de martirio en la mano derecha y libro de rezos monacales en la izquierda ${ }^{74}$. En 1595 se lleva a cabo la petición de Carmona para nombrar patrono a San Teodomiro, obteniéndose la autorización para obtener la bula que le declarase patrono ${ }^{75}$.

Imagen 5. San Teodomiro (1761).

Fuente: El Curioso Carmonense. La Historia de Carmona que en el año de 1628 escribió el P. Fr. Juan Baptista de Arellano se divide en diez mapas para mayor diversión de los curiosos con algunas notas, y adicciones, y se continua hasta el presente año de 1787 por el Curioso Carmonense, Carmona, 1787, I.H. (CSIC) F.A. G-374, f. 132 r.

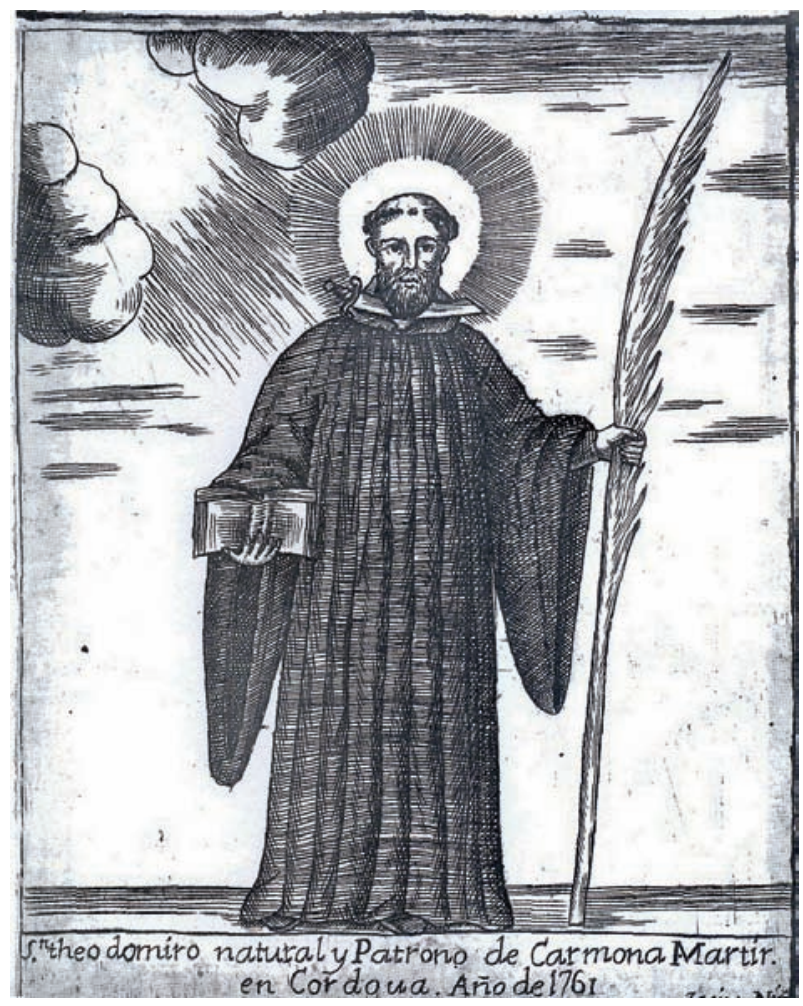

74 CEBREROS, Francisco Javier: Vida del señor San Teodomiro mártir, natural y patrono de la ciudad de Carmona, Madrid, 1805, B.N. 1/4410.

75 “[...] quedó elegido y reconocido de todos por especial abogado, protector y patrono de la ciudad de Carmona, y guardándose su fiesta con la mayor devoción”, en FERNÁNDEZ LÓPEZ, Manuel: Historia de la Ciudad de Carmona, Sevilla, 1886, B.N. 2/7682, p. 358. 
Las fundaciones del colegio jesuita y de la obra pía se pusieron bajo el "título y advocación de San Teodomiro”. El P. Rodrigo Figueroa consiguió traer una reliquia de la iglesia de San Pedro de Córdoba, más concretamente una canilla, en 1620, después de dar su aprobación fray Diego Mordones, obispo de Córdoba, colocándose el hueso en el altar mayor ${ }^{76}$. El cabildo lo eligió en 1626 como patrono de la villa, otorgando el breve Clemente VIII ${ }^{77}$. Así, los regulares se encontraron con una devoción, que apoyan y hacen suya, dándole culto con la mayor brillantez posible y llegando incluso a disputar con la parroquia de Santa María la celebración oficial de su fiesta. En 1622 el rey tuvo que intervenir en la disputa, ordenando que se hiciese en la iglesia Mayor, como era costumbre. La vinculación con el colegio fue tal, que cuando los jesuitas cayeron en “desgracia” la devoción comenzó a declinar. La reliquia del santo fue entregada por orden del consejo de Castilla, en 15 de agosto de 1771, a la iglesia parroquial de San Pedro en Carmona.

\section{La ciudad y el arte}

La Historia proporciona una rica información sobre la ciudad de Carmona, sus lugares principales y varios de sus edificios más emblemáticos, eclesiásticos y civiles, algunos conservados; tampoco se deben olvidar los datos sobre el recorrido que hacían las procesiones y entierros o los contactos con otras ciudades y aldeas cercanas. A lo largo de su historia el colegio ocupó tres lugares diferentes y sus miembros, ayudados por los vecinos, construyeron la iglesia de San Teodomiro, hoy del Salvador, y su residencia, el actual Ayuntamiento.

La ciudad se dividía en dos zonas claramente diferenciadas: la plaza Baja o el Arrabal y la plaza Alta, de Arriba o del Salvador, donde se localizaba el poder político, alrededor del cabildo, y religioso, con la presencia de varias parroquias y conventos de órdenes religiosas. Cuando llegaron los jesuitas se asentaron en la primera, ya que el fundador poseía varias propiedades allí. Aunque estaban cerca de la parroquia más importante, la de San Pedro, pronto se advierte el deseo de trasladarse al considerar su lejanía del centro de la ciudad y las malas condiciones climáticas del lugar, calor en verano y lluvias y viento en invierno ${ }^{78}$.

En 1622 la iglesia se inauguró, con planta rectangular y medianas proporciones $^{79}$. Además, contaba con confesionarios para mujeres, púlpito, coro, tribunas con celosías y sacristía. En el presbiterio estaba el retablo mayor y, en su centro, se encon-

76 Historia del Colegio de Carmona (Agosto de 1620 a 1754) escrita por el P. Juan B $B^{a}$ de Algaba, A.P.T.S.I., C-198 (126), ff. 18 v.-19 r.

77 GARCÍA RODRÍGUEZ, Antonio: Teodomiro, Carmona, Consejo de Hermandades y Cofradías de Carmona, 1995, pp. 45-50 y 70-75.

78 En el manuscrito se describe así:

“[...] por estar casi a lo último del lugar, en una gran plaza, que el verano por bañada del sol

y el invierno por expuesta a lluvia y a vientos, sería muy incómodo a los estudiantes para

venir a las aulas y a los demás fieles para frecuentar nuestra iglesia”.

Historia del Colegio de Carmona (Agosto de 1620 a 1754) escrita por el P. Juan Ba de Algaba, A.P.T.S.I., C-198 (126), f. $17 \mathrm{v}$.

79 Historia del Colegio de Carmona (Agosto de 1620 a 1754) escrita por el P. Juan Ba de Algaba, A.P.T.S.I., C-198 (126), ff. 21 r.-21 v. 
traban un lienzo de San Teodomiro, flanqueado por dos hornacinas doradas en las que se ubicaban las imágenes de San Ignacio y San Francisco Javier. En un lateral de la iglesia, posiblemente al lado del Evangelio, figuraba un retablo dedicado a Nuestra Señora, así como un altar que alojaba un cuadro de advocación de San Francisco de Borja ${ }^{80}$. Sin embargo, los religiosos desean mudarse dentro de las parroquias de San Bartolomé y San Salvador. En primer lugar, ocuparon un edificio en la calle de Santibáñez, dentro de la parroquia de San Bartolomé. El P. Rodrigo de Figueroa, tercer superior, protestó por la incomodidad del sitio para el desarrollo de los ministerios y estar lejos, al mismo tiempo, del Arrabal y del centro de la ciudad ${ }^{81}$.

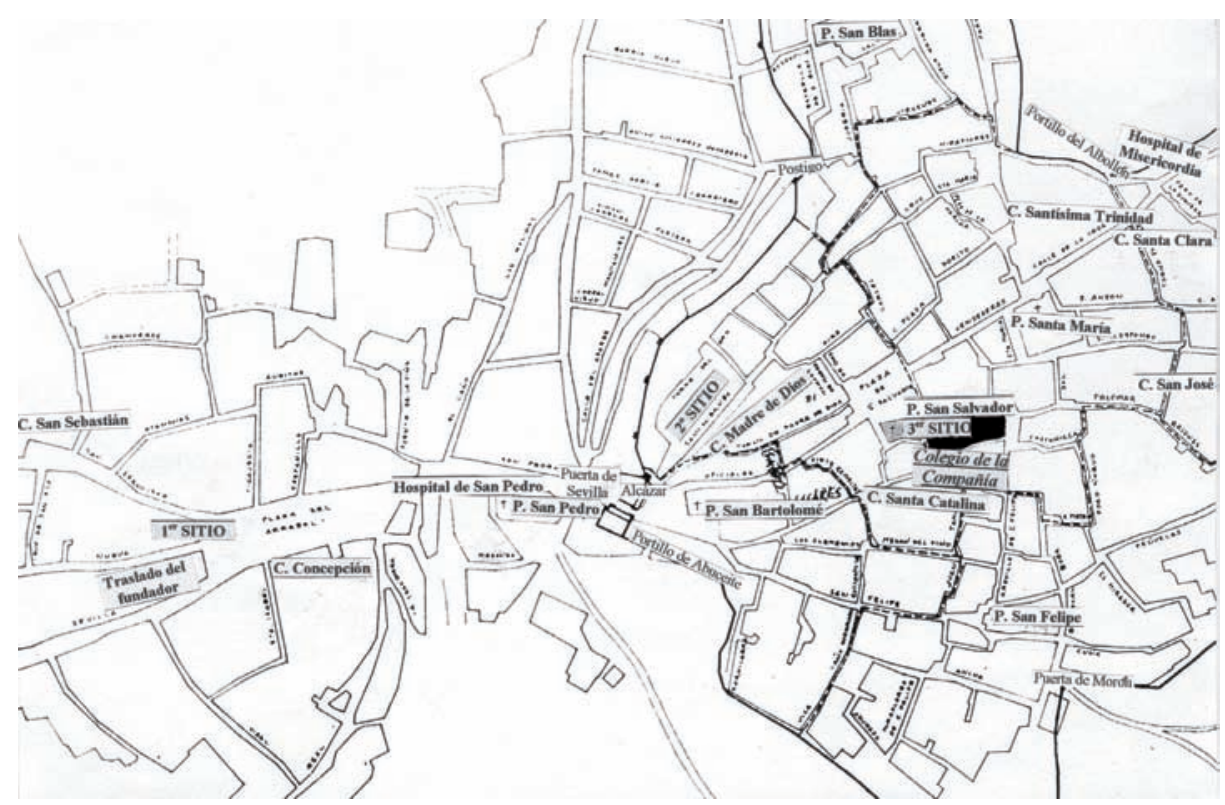

Plano 1. Los traslados del Colegio Jesuita en Carmona

Fuente: Elaboración propia a partir del mapa de GONZÁLEZ JIMÉNEZ, Manuel: El concejo de Carmona a fines de Edad Media (1464-1523), Sevilla, 1973, p. 35

80 MARTÍN PRADAS, Antonio y CARRASCO GÓMEZ, Inmaculada: op. cit, p. 525.

81 Así lo señala el manuscrito:

"[...] por ser sombrío y muy húmedo a causa de ser batiente de cuesta y muy caro así para confesarse las casas necesarias para nuestra morada, como para igualarse por ser todo cuestas por dos partes diferentes, y por estar junto al Adarbe o Muro, que impedía dilatarse, y muy arrinconada, respecto de toda la población de Carmona, con cierta actual experiencia, que ni del Arrabal que está de una parte, ni de la ciudad que está a la otra, acudía gentío de consideración a nuestros ministerios [...]”

Historia del Colegio de Carmona (Agosto de 1620 a 1754) escrita por el P. Juan Ba de Algaba, A.P.T.S.I., C-198 (126), f. 19 r. 
Los jesuitas buscarán instalarse en el mejor lugar posible y su objetivo es ambicioso, la plaza del Salvador. Este tercer traslado se logró en un breve espacio de tiempo, dos años, poniéndose de manifiesto la popularidad y el poder alcanzados. El colegio se instaló en unas casas de la plaza Alta, junto a la iglesia Mayor, por dos principales razones, la presencia de los estudiantes y la cercanía de los órganos de gobierno ${ }^{82}$. A finales del siglo XVII, la iglesia jesuítica se mostraba incapaz de acoger al creciente número de fieles y los religiosos comprendieron que era necesario construir un nuevo templo ${ }^{83}$, aunque la propuesta, en principio, no se atendió por el enorme coste y riesgo que suponía. Sin embargo, el proyecto va a contar con el empeño del rector, varias promesas de los vecinos y el apoyo de Fernando Castellano, provincial de Andalucía. Esta construcción constituyó el esfuerzo más grande, desde el punto de vista económico, que tuvo que asumir el colegio durante su existencia y duró desde 1698 hasta 1720. El 4 de junio de 1700 el cabildo municipal ordinario recibió la solicitud, lo que suponía los pies de la capilla cinco varas, hasta encontrarse con el arroyo que atravesaba la plazuela y tres varas cada brazo del crucero ${ }^{84}$.

El proyecto se encomendó al maestro Leonardo de Figueroa. El diseño recordaba a la iglesia de San Hermenegildo de Sevilla por su planta oval y centralizada. Los miembros de la Compañía querían un oratorio amplio para acoger a numerosos fieles y la dirección pasó a manos de Pedro Romero y sus hijos, quiénes diseñaron una planta de cruz latina con tres naves y transepto. Dos de las exigencias que pusieron al nuevo edificio fueron la solidez y la perdurabilidad del mismo. Después de su muerte se encargó de la fábrica Félix Romero, que sí aparece citado en la Historia. Su fallecimiento se produjo cuando estaba montando el anillo de la cúpula, pasando la dirección de la obra a otro Pedro Romero. El aspecto exterior de la iglesia, con la torre inacabada que coronó el ángulo noroeste, quedó dominado por la cubierta central. Como complemento de la iglesia se erigieron la sacristía y dos capillas ${ }^{85}$.

82 Así se resumen las razones del traslado:

“[...] primera estar dicha isleta en medio y lo mejor de la villa, cerca de la plaza e iglesia Mayor, con una plazuela delante que llamaban de Santa Bárbara, muy a propósito para concurso y desahogo de escuela y de estudiantes y lejos de los demás conventos de religiosos por estar estos fuera en el Arrabal, y solo los nuestros dentro de los muros donde vivía toda la gente principal y estar dicha isleta toda cercada de la vecindad mucha y muy honrada; segunda porque el común del regimiento, corregidor, caballeros, clerecía, beneficiado, vicario y abad mayor, a una voz y de conformidad todos deseaban nuestra mudada y tenernos juntos, así para aconsejarse con nosotros consultados sus casos y tenernos a manos en sus muertes: ofreciéndonos mientras no tuviésemos iglesia la capilla de Santa Bárbara en la iglesia Mayor que es muy capaz y con sagrario donde con grande comodidad, aunque de prestado podíamos tener y ejercitar todos nuestros ministerios. Alegándose a esto, quedando nosotros gusto a los deseosos de tenernos juntos, así sobre hacer nuestro negocio, que nos convenía, les ganábamos las voluntades y la benevolencia para hacernos presencia y acompañarnos en todas ocasiones que se ofreciesen. Enviose a nuestro padre Provincial este acuerdo tomado acerca del sitio y firmado de todos los dichos padres en ocho de enero de mil seiscientos y veinte y uno, y habiendo leído y considerándose conforme con él y encargó al P. Rodrigo de Figueroa dispusiese con brevedad la mudanza”.

Ibídem, f. $19 \mathrm{v}$.

83 Sobre la construcción de la iglesia nueva: MARTÍN PRADAS, Antonio y CARRASCO GÓMEZ, Inmaculada: op. cit., pp. 521-538.

84 GARCÍA RODRÍGUEZ, Antonio: op. cit., pp. 45-50.

85 GONZÁLEZ ISIDORO, José: “II. Memoria de los edificios...”, pp. 148-154. 
El 4 de noviembre de 1720 el padre Antonio del Puerto, rector del colegio, invitó a la Ciudad a la inauguración de la iglesia. Las fiestas duraron varios días y se enorgullecieron de "tener una iglesia, que es hoy por boca de todos, la mejor de la

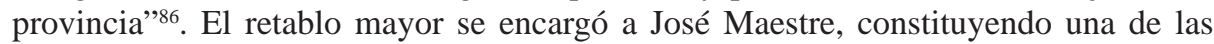
producciones retablísticas más importantes de la ciudad, finalmente concluida en 1722. La gran hornacina central se puede dividir en tres registros: inferior para el sagrario, intermedio manifestador (hoy convertido en hornacina) y por último la hornacina de San Teodomiro. La central del ático albergaba el relieve de San Ignacio en la visión de la Storta, atribuido a Duque Cornejo ${ }^{87}$.

\section{La expulsión}

El relato finaliza en 1754, por lo que nada sabemos de la disolución de la Orden a través de este texto. El 27 de febrero de 1767 el rey Carlos III dictó la pragmática de expulsión de la Compañía de Jesús ${ }^{88}$. Una de las razones que se expuso para la toma de esta decisión fue la estrecha vinculación de la Orden con el Papa ${ }^{89}$. La noche o madrugada del 2 de abril un tropel de variopintos carruajes llegó a las puertas del colegio, los jesuitas carmonenses fueron arrestados y un día después trasladados a Jerez de la Frontera y desde allí a Cádiz, con dirección hacia los dominios pontificios ${ }^{90}$. Desde 1769 la iglesia quedó como oratorio privado y comenzó a ser desmantelada, ingresando sus objetos dentro del patrimonio de las iglesias de Santa María, San Bartolomé, San Blas o San Felipe. El 20 de abril de 1783 pasó a ser parroquia del Salvador ${ }^{91}$ y se suprimió la

86 Historia del Colegio de Carmona (Agosto de 1620 a 1754) escrita por el P. Juan B $B^{a}$ de Algaba, A.P.T.S.I., C-198 (126), f. 177 r.

87 HERRERA GARCÍA, Francisco Javier, QUILES GARCÍA, Fernando y SAUCEDO PRADAS, Consuelo: Carmona barroca: panorama artístico de los siglos XVII y XVIII, Sevilla, Ayuntamiento de Carmona, 1997, pp. 77-78.

88 Los jesuitas son expulsados de Portugal (1759), Francia (1764) y España (1767). El papa Clemente XIV, presionado por los monarcas borbónicos, disuelve la Compañía el 21 de julio de 1773 con el breve Dominus ac Redemptor. El rey de Prusia, Federico II el Grande, y la emperatriz de Rusia, Catalina II la Grande, grandes admiradores de la labor educativa y del conocimiento de los jesuitas, se negaron a aceptar el documento Dominus ac Redemptor de 1773. En estos países la orden se mantuvo hasta 1814, año en que el papa Pío VII la restauró. MARTÍN RIEGO, Manuel: “Sevilla de las Luces” en C. ROS (dir.), Historia de la Iglesia de Sevilla, Sevilla, Castillejo, 1992, pp. 557-560 y PINEDO, Isidoro: op. cit., pp. 697-708.

89 Desde principios de la década de los años 90 hasta la actualidad, el área de Historia de Moderna de la Universidad de Alicante, ha centrado su investigación en la temática jesuita, especialmente en lo que se refiere a la expulsión de España, bajo la dirección del Dr. Enrique Giménez López. Véase GIMÉNEZ LÓPEZ, Enrique (ed.): Expulsión y exilio de los jesuitas españoles, Alicante, Universidad de Alicante, 1997 y www. cervantesvirtual.com/bib_tematica/jesuitas/index.shtml.

90 GARCÍA RODRÍGUEZ, Antonio: op. cit., pp. 45-50 y 70-75 y MIRA CABALLOS, Esteban: "Los jesuitas de Carmona: fundación, expulsión y expolio” en www.hermandaddelaesperanza.es/historia/e_articulos/ articulo_06.doc.

91 GARCÍA RODRÍGUEZ, Antonio: op. cit., pp. 70-75 y www.hermandaddelaesperanza.es/iglesia.htm (página web sobre la iglesia del Divino Salvador). Son también interesantes los artículos de Esteban Mira Caballos “¿Por qué se trasladó la parroquia de El Salvador al templo de los jesuitas?” en www.hermandaddelaesperanza.es/historia/e_articulos/articulo_04.doc y “El primitivo templo de El Salvador y las Hermandades establecidas históricamente en él” en www.hermandaddelaesperanza.es/historia/e_articulos/articulo_05.doc. 
advocación de San Teodomiro ${ }^{92}$. La antigua iglesia de San Salvador, en estado ruinoso, pasó a ser lugar profano, construyéndose casas habitables en ella. A partir de este momento y prácticamente hasta principios del siglo XIX, la antigua iglesia jesuítica sufrió diferentes remodelaciones. Desde 1911 la iglesia del Salvador es filial de la parroquia mayor de Santa María y su edificio es uno de los de mayor prestancia y envergadura artística de todo el caso urbano ${ }^{93}$.

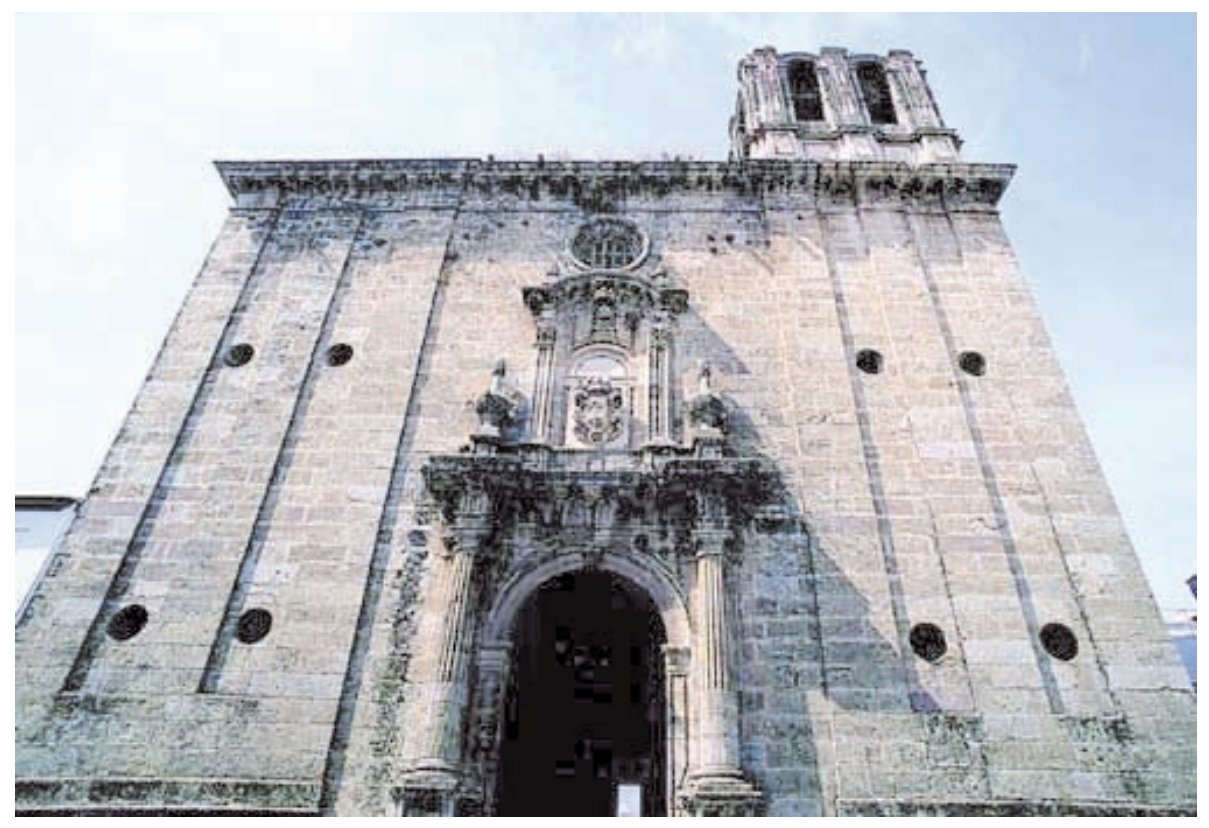

Imagen 6. Iglesia del Salvador (antigua Iglesia Jesuita de San Teodomiro).

Fuente: www.carmona.org

Por último, no hay que olvidar que el templo tenía anexa la residencia, que por real orden de 16 de abril de 1769 debía pasar a ser casa de pupilaje. Allí se recogerían las escuelas de primeras letras fundadas por Juan Berrugo Cansino en 1754. Sin embargo, el destino le tenía reservado otro servicio a la ciudad: a partir de 1837 comenzaron las obras para adaptarlo a Ayuntamiento ${ }^{94}$.

92 Así lo señalaba un historiador de Carmona a finales del siglo XIX:

“[...] siendo de los regulares de la Compañía de Jesús, por real cédula se destinó para trasladarse a ella la parroquial del Salvador del mundo. Por este incidente perdió dicha iglesia la advocación y título de San Teodomiro y tomó el de parroquial del Salvador. Hasta una estatua del santo, obra del célebre artista Cornejo, que ocupaba el trono principal del altar mayor, fue quitada y sustituida con otra del nuevo titular".

FERNÁNDEZ LÓPEZ, Manuel: Historia de la Ciudad de Carmona, Sevilla, 1886, B.N. 2/7682, p. 360.

93 CABEZA MÉNDEZ, José María: “Iglesia del Salvador” en Estela. Revista Cultural e Informativa de Carmona, 2005, pp. 20-22.

94 www.carmona.org 


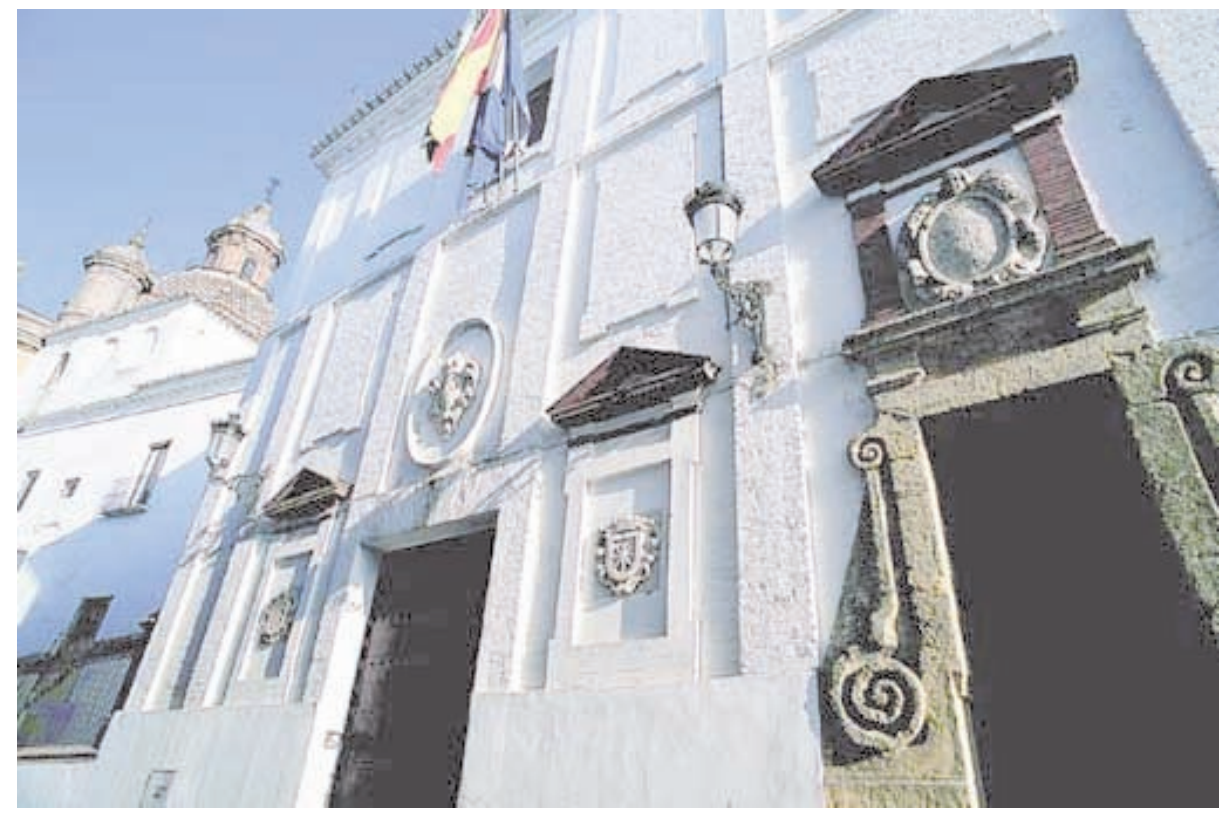

Imagen 7. Ayuntamiento de Carmona (antigua Residencia de los Jesuitas).

Fuente: www.carmona.org 
